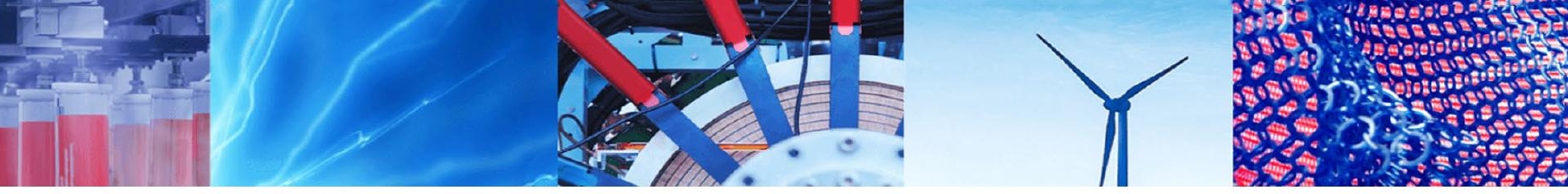

Research Article

\title{
Export of nutrients to the sea in a karstic basin in the west of Cuba
}

\author{
José Miguel Febles Díaz ${ }^{1}$ (I) José Manuel Febles González ${ }^{1}$. Julia Azanza Ricardo ${ }^{1}$ María Sotelo Pérez ${ }^{2}$. \\ Thalia González Calvo ${ }^{3}$
}

Received: 4 July 2020 / Accepted: 13 October 2020 / Published online: 29 October 2020

(c) Springer Nature Switzerland AG 2020

\begin{abstract}
Few studies relate soil water erosion and associated nutrient losses in flat karst landscapes to marine waters. This is due to the complexity of these peculiar ecosystems, given their scarce distribution in the world (20\%) and the low erosion rates. Adding that in Cuba these marine waters, where these soils discharge are oligotrophic with a strong historical reduction of their nutrients as a result anthropic-engineering causes; therefore, these are one of their main sources of nutrients. The present research constitutes an approximation of the influence of soil erosion on La Teresa basin, a karstic environment where there are practically no permanent surface streams, to the marine platform of the Batabanó Gulf. The influence of soil erosion and its associated nutrients $\left(0.064 \mathrm{~kg} \mathrm{ha}^{-1} \mathrm{yr}^{-1}(2.3 \mathrm{t})\right.$ of $\mathrm{P}, 1 \mathrm{~kg} \mathrm{ha}^{-1} \mathrm{yr}^{-1}$ (35 t) of $\mathrm{N}$ ) on marine waters coincides with the oligotrophication effect suffered by the island's water bodies reported by Baisre (Biogeochemistry 79:91-108, 2006) and Baisre and Arboleya (Fish Res $81: 283-292,2006$ ) as a result of the damming by agricultural programs.
\end{abstract}

Keywords Export of nutrients · Soil erosion · Gulf of Batabanó

\section{Introduction}

Numerous studies have been carried out to determine the amount of nutrients that reach the marine platforms coming from the soils, most of them in permanent water flows [44],Farian et al., 2003; [1, 54, 71, 74]. An analogy of this type of (permanent) flow is that of a highway for transporting nutrients between sea and land. However, in flat karst regions (Fig. 1), this highway turns into a series of labyrinthine routes that only work in an episodic way, given the superficial-intermittent drainage pattern that characterizes them.

In other words, the speed of diffusion of nutrients in flat karst regions without permanent surface streams varies greatly from one sector of the basin to another according to the peculiarities of the relief and permeability of the underlying stone material, in some cases their incorporation occurs directly into the drainage network which allows their transmission in a rapid manner, while in other sectors they are incorporated in areas distant from the network of karstic channels of "organized heterogeneity" where they can reside in the surroundings for a long time, which singularizes the karstic landscape, dynamics that coincide with those described by Van Beynen and Towsend [95] and Fernández de Ortega [30]. Inside the karst massif (which is not the aim of the research). The karst aquifer structure is characterized by conduit, fracture and matrix flow resulting in fast (e.g., conduit) and slow (e.g., fracture and matrix) flow pathways $[33,47]$. The

Electronic supplementary material The online version of this article (https://doi.org/10.1007/s42452-020-03679-x) contains supplementary material, which is available to authorized users.

$\square$ José Miguel Febles Díaz, jmifebles@gmail.com; José Manuel Febles González, febles@rect.uh.cu; Julia Azanza Ricardo, jaricardo@instec.cu; María Sotelo Pérez, maria.sotelo.perez@urjc.es; Thalia González Calvo, tgonzalez2496@yahoo.com | 1'University of Havana, Havana, Cuba. ${ }^{2}$ University of Rey Juan Carlos, Paseo Artilleros, s/n, 28032 Madrid, Spain. ${ }^{3}$ Centro de Investigación y Desarrollo de Medicamentos, Havana, Cuba. 


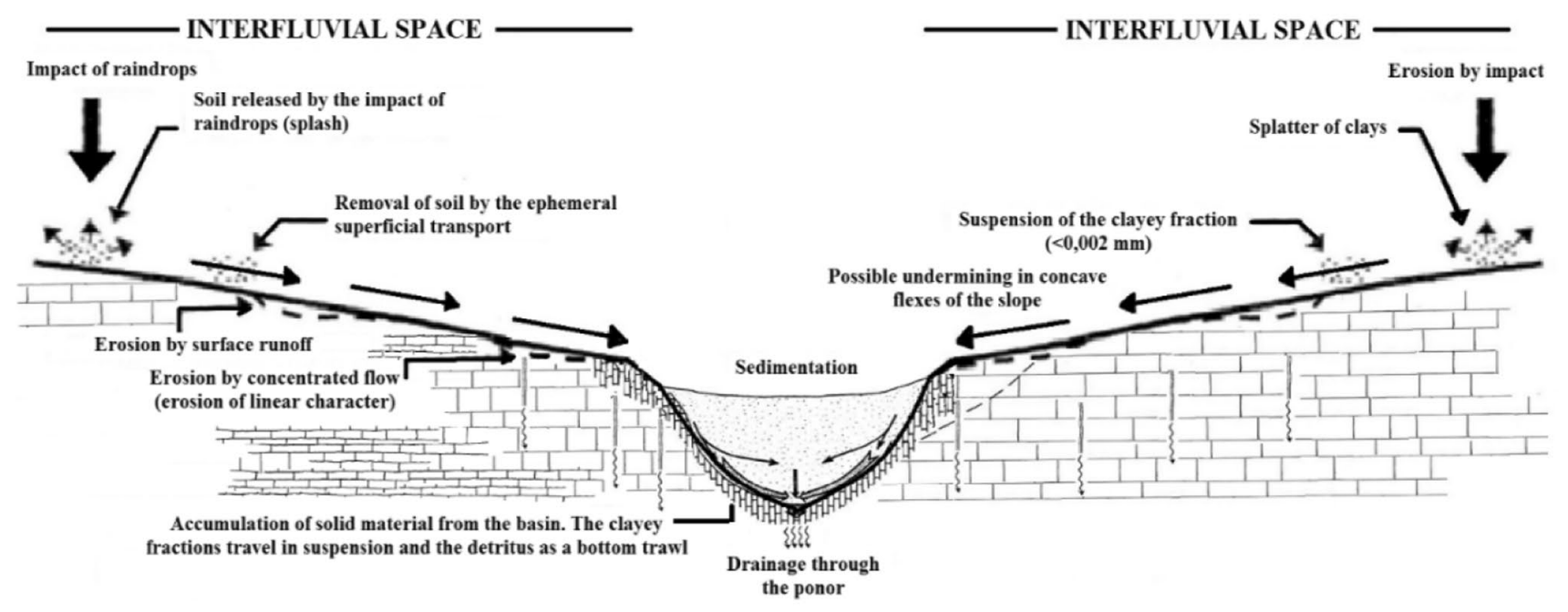

Fig. 1 Karst dynamics-erosion in inter-river space in the middle of the basin

relative proportions of two flows will influence discharge and nutrients distribution.

In this context, the MMF (Morgan-Morgan-Finney) soil erosion model [73] plus the Verstraeten and Poesen [99] equation to estimate the nutrients bound to the eroded sediment, especially in the roll that performs the size of the particles, through the variable of nutrients sediment trap (NTE), which allows us a discussion between the amount of sediment caused by erosion, but also the factor of sedimentation by the texture of that sediment removed.

The above mentioned, contribute to solve this incapacity, compared to other models existing in the literature for the estimation of nutrient exports, because the soil erosion models are as follows: (a) Sensitive to the estimation of removal by areal runoff (laminar erosion), which is the main phenomenon of surface transport in the absence of permanent flows (b) They are sensitive to the selective removal of soil particles, which will prevail in this type of environment. (c) These can deal with diffuse runoff; this is due to the lack of morphometric potential, for the development of linear forms of erosion [43]. In summary, soil erosion models focus more on interfluvial processes.

The Cuban archipelago is strongly influenced by the sea, accentuated by the elongated and narrow shape of the land areas with a predominance of coastal karst plains and with low slopes which limits the development of large river systems. It is also characterized by a marine system, which has strong connectivity at three levels of scale, inter-platform, mangrove, grassland and reef [42], between gulfs and within the Caribbean Sea [36]. Due to the location of Cuba in the oligotrophic Caribbean Sea, in absence of significant processes of coastal upwelling and because the very small tidal range; the runoff and river discharge, delivering terrestrial material in particulate and dissolved form, is the most important source of nutrients supporting Cuban marine coastal fisheries [8].

On the island through a program entitled "Voluntad Hidráulica [Hydraulic Will]" in 1962, which aims to create infrastructure and mechanisms to control phenomena of excess (flooding due to storms and cyclones) or lack of water (drought) and its consequences. The mechanism of execution was an extensive "Programa Constructivo de Obras Hidráulicas [Construction Program of Hydraulic Works]," which increased the capacity of water reservoirs to 48 million cubic meters stored in 13 reservoirs in 1959 to more than 9000 million cubic meters in 240 reservoirs and more than 800 micro-dams. Within this program, one of the most outstanding works is the "Dique Sur [South Dike]," which extends from the Batabanó outlet in Mayabeque to Majana Beach in Artemisa (Fig. 2), approximately $51.7 \mathrm{~km}$ long; between 7 and $8 \mathrm{~m}$ wide in the crown; an average height of $2 \mathrm{~m}$ above sea level and a capacity of 45 million cubic meters of water in a space of 13,000 hectares. This has altered the surface drainage and, in some cases, even the subsurface drainage of Cuba $[7,8,9,39,68]$.

On the other hand, the waters of the La Teresa basin drain into the Gulf of Batabanó, which is a source of important marine resources and human settlements that live from them. This contributes to $66.5 \%$ of the national capture of moorland crab (Menippe mercenaria) [13] and $75 \%$ of the national capture of Spiny Lobster (Panulirus argus) [90]. The most caught snapper species on this shelf have been lane snapper (Lutjanus synagris), mutton snapper (L. analis), grey snapper (L. griseus), yellowtail snapper (Ocyurus chrysurus) and cubera snapper (L. cyanopterus) [16]. The International Union for the Conservation of Nature (IUCN) classifies L. cyanopterusas vulnerable on the Red List of Threatened Species (IUCN 2017). 
Fig. 2 Location and physicalgeographical characteristics of the basin in the Southern Havana-Matanzas Karstic Plain, Cuba

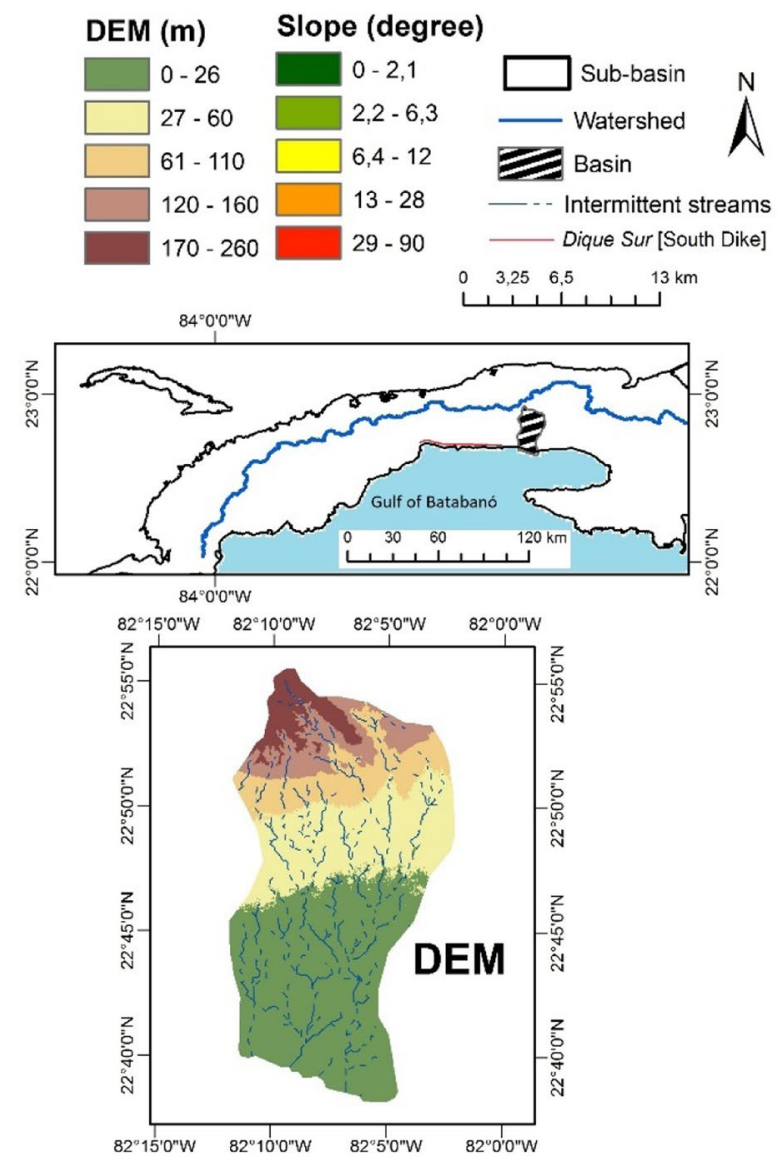

Landing data on this area indicate that in the 70s, about $35 \%$ of the total finfish catch was constituted by snappers, but in 1990 this percentage dropped to 18\% [14]. Taking into account that the basin belongs to the physical geographical unit Habana-Matanzas Karst Plains, where the predominant soil is Ferralitic, with a change from this to Humic Calciorphic in the part near the coastline. The most common land use in the plain is for various crops and pastures. Its surface runoff flows into the sea, not truncated by the southern dike. This makes it a good pilot basin for a first approximation of the biogeochemical cycle between the plain and the gulf.

In this context, the scarce research developed on the export of nutrients in the island has been characterized by an essentially linear domain (stream and river), such as those reported by Baisre [7], Baisre and Arboleya [8], without yet knowing the contribution of soil runoff, which is of an areal component. Taking into account this background, the aim of this work is to estimate the amount of nutrients that reach the sea in a karst basin from water erosion and to give a first approximation of its influence.

\section{Materials and methods}

\subsection{Description of the area of study}

The research was carried out in the La Teresa karstic basin located on the southern coast of Cuba (Fig. 2), belonging to the Southern Havana-Matanzas Karstic Plain (Table 1), in Mayabeque province.

The region has a climate that characterizes the rest of the country, which can be considered as tropical with alternating humidity (Fig. 3).

The geomorphology corresponds to a plain with a system of flat terraces made up of carbonate rocks from the Güines mid-late Miocene; Cojímar early-middle Miocene; Colón Oligocene-Miocene inferior, formation and marshy deposits Holocene [55]; the predominant soils correspond to the Red Ferralitic Grouping [81, 92], destined basically to various crops and pastures (Fig. 4).

\subsection{Methodology used}

In order to calculate the amount of nutrients exported to the sea by soil erosion (Fig. 5), the MMF parametric erosion model was applied (Table 2) [73], based on the dynamics 
Table 1 Main morphometric parameters of the La Teresa karstic basin

\begin{tabular}{lllll}
\hline Description & Unit & Values & Interpretation & Methods \\
\hline Shape of the basin & - & 0,40 & Very wide & Horton [53] \\
Drainage density & $\mathrm{km} \cdot \mathrm{km}^{-2}$ & 0,81 & Low & Strahler [91] \\
Average slope & Grade; \% & 1,$64 ; 2,87 \%$ & Light & Alvord (Horton [51]) \\
Basin area & $\mathrm{Km}^{2}$ & 362 & - & - \\
Average depth & $\mathrm{m}$ & 49 & - & - \\
\hline
\end{tabular}

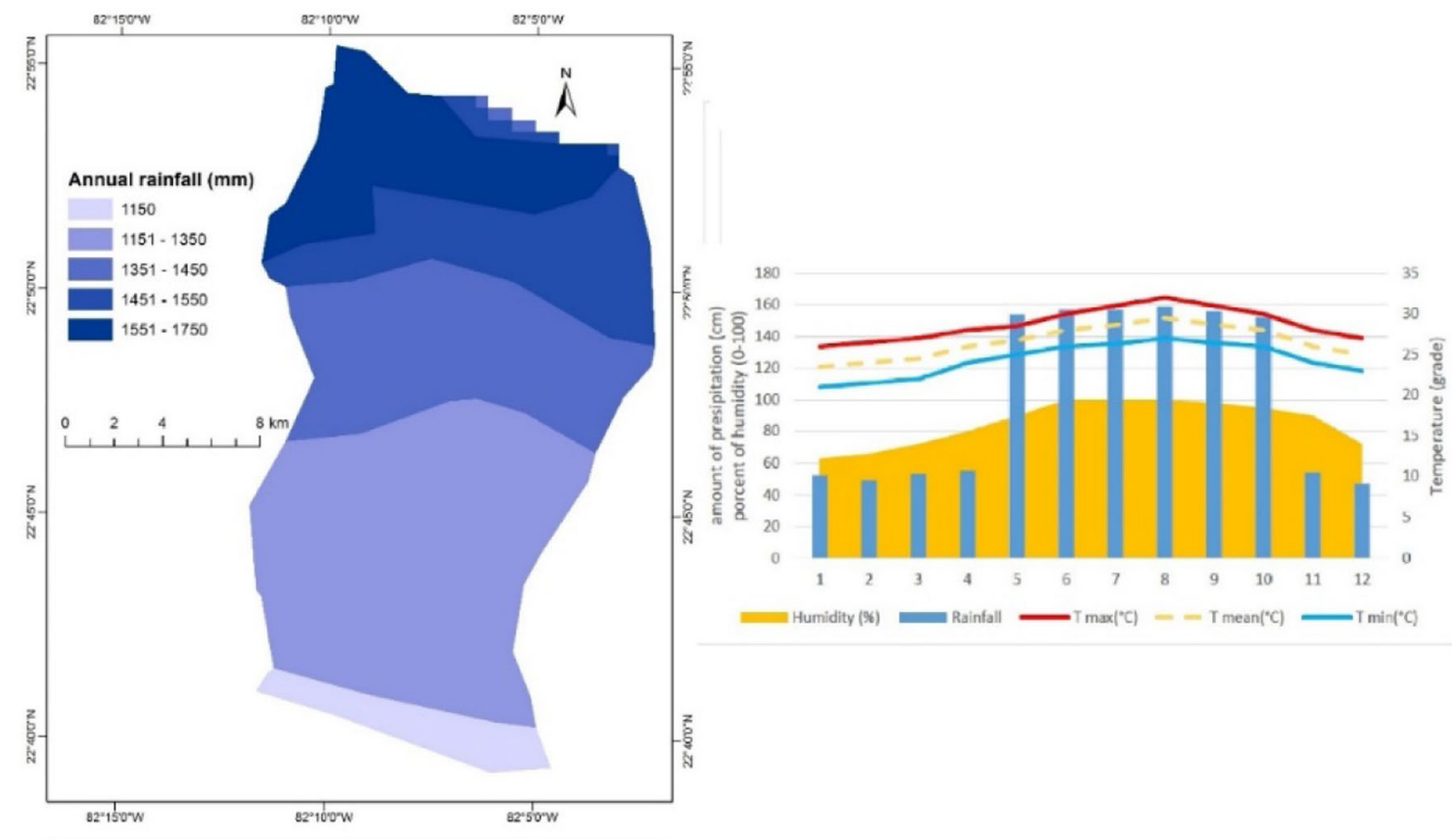

Fig. 3 Accumulated rainfall between 2010-2014 in the basin (INRH, 2014)

of erosion processes, soil properties, climatic characteristics and conditions of use, which made it possible to evaluate the magnitude of losses. While the Verstraeten and Poesen [99] equation was used to quantify the export of nutrients bound to the eroded sediment estimated by MMF, this equation is designed to be used in small basins, so the sub-basins were mapped (Fig. 2).

The MMF erosion model [73] was used to determine the quantitative values of soil loss, which has already been used in Cuba in similar conditioner by Vega and Febles [96]; Febles et al. [27]; Vega et al. [97],Febles Díaz and Vega [25].

$E=R\left(11,9+8,7 \cdot \log _{10} l\right)$

where $E=$ Kinetic energy of rain (Wischmeier and Smith, 1958) (J/m2); I=Typical value of the rain intensity for tropical climates $(\mathrm{mm} / \mathrm{h})$

$Q=R \exp \left(-R_{\mathrm{c}} / R_{0}\right)$
$R=1000 \cdot \mathrm{MS} \cdot \mathrm{BD} \cdot \mathrm{RD}\left(E_{\mathrm{T}} / E_{0}\right)^{0,5}$

$R_{0}=R / R_{n}$

where $Q=$ Volume of superficial flow ( $\mathrm{mm}) ; R=$ Annual rainfall amount $(\mathrm{mm}), R_{\mathrm{c}}=$ Critical value of moisture storage; $R_{0}=$ Average rain of the rainy days per year $(\mathrm{mm} /$ day); $M S=$ Soil moisture (\%); BD = Soil density $(\mathrm{kg} / \mathrm{m3})$; $\mathrm{RD}=$ Depth of rooting $(\mathrm{m}) ; E_{\mathrm{T}}=$ Current Evapotranspiration; $E_{0}=$ Potential evapotranspiration.

In this phase, the dispersed soil splash rate $(F)$ and the surface flow transport capacity $(G)$ are evaluated by means of the following equations:

$F=K\left(E e^{-a A}\right)^{b} \cdot 10^{-3}$

where $F=$ Particles mobilized by splash $(\mathrm{kg} / \mathrm{m} 2)$, $K=$ Index of erodability, $E=$ Kinetic energy of rain $(\mathrm{J} / \mathrm{m} 2)$, 

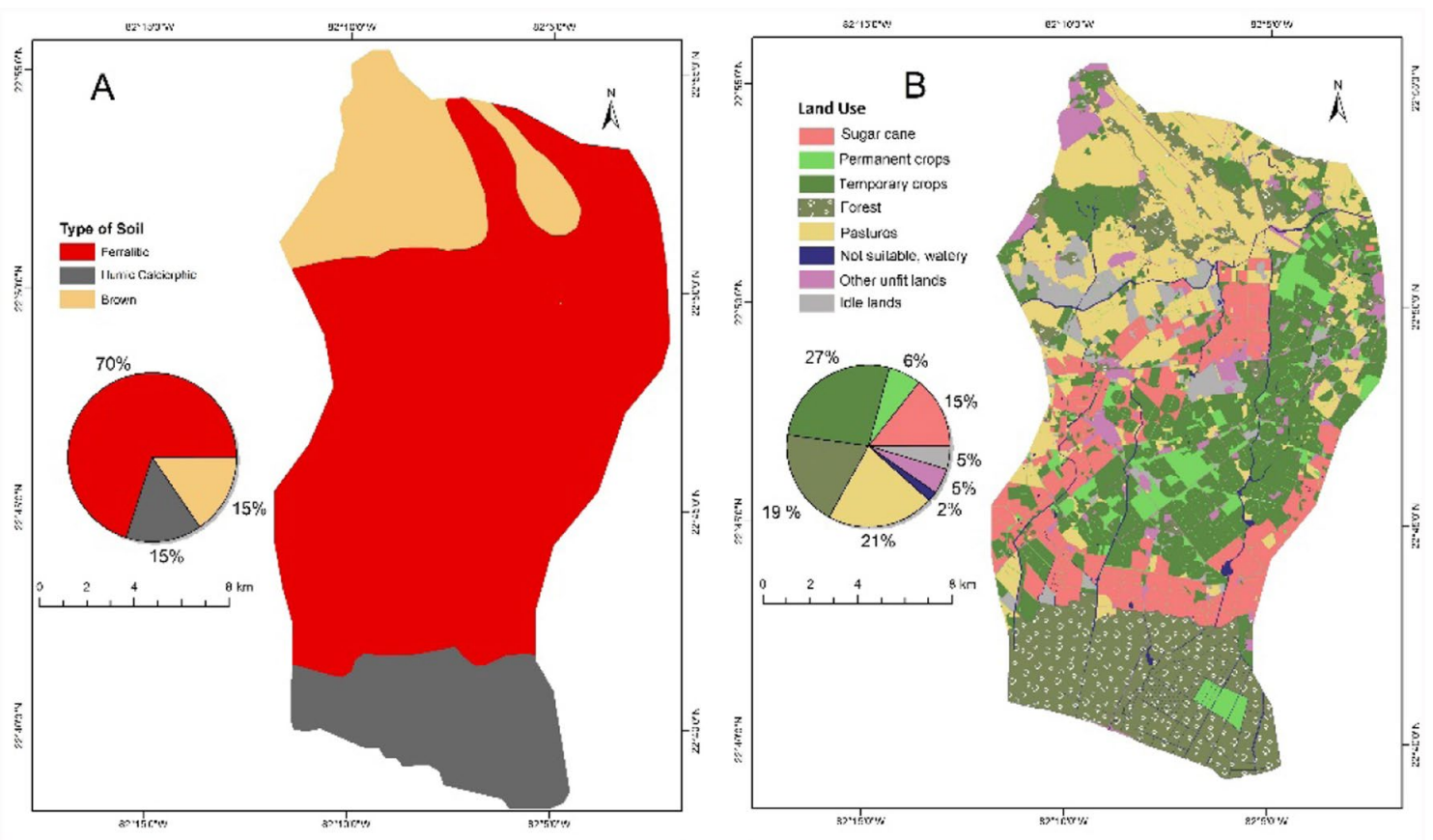

Fig. 4 a Soil distribution and $\mathbf{b}$ use conditions in the basin [69]

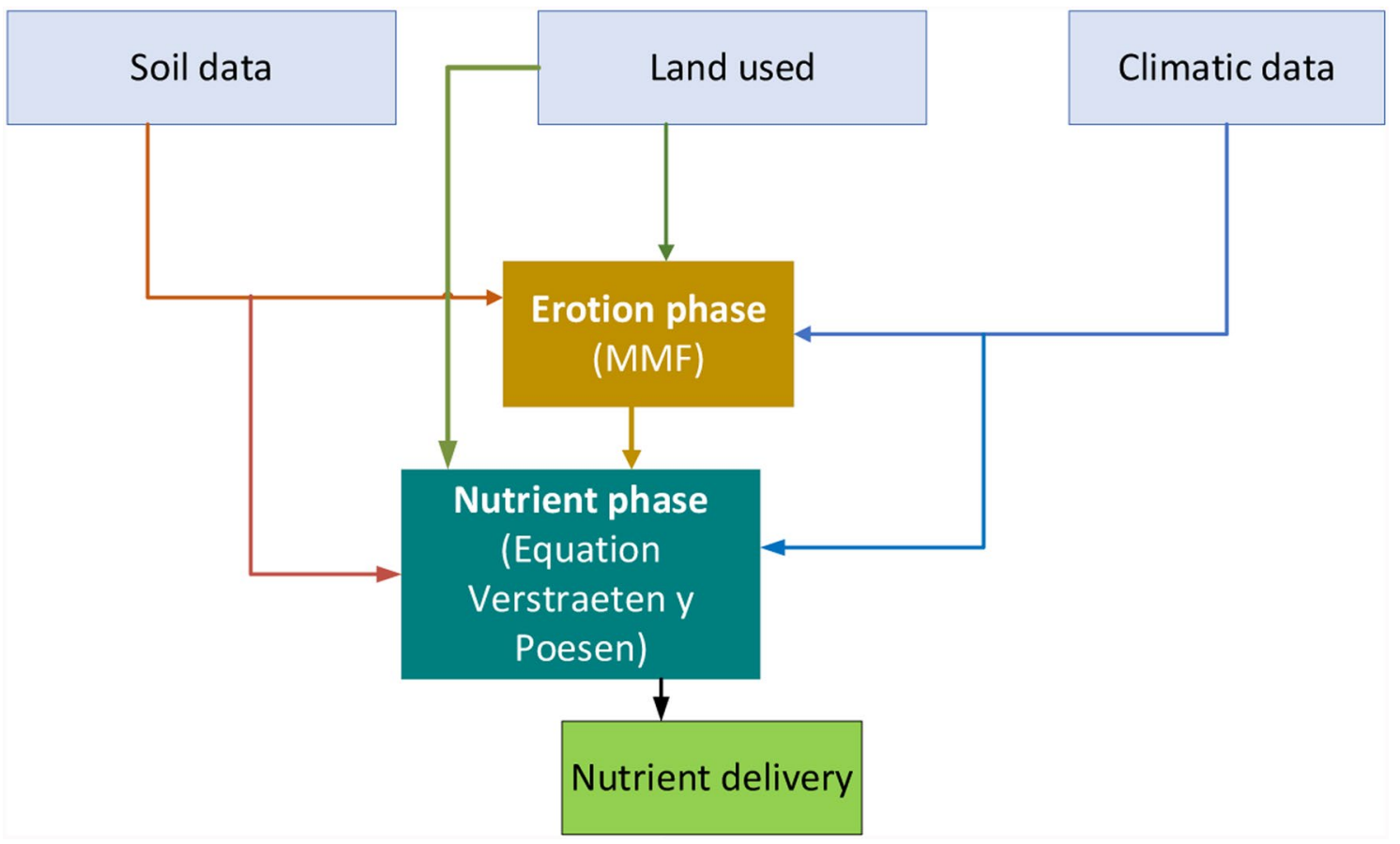

Fig. 5 Methodology for estimating nutrient flows to the sea in river basins with intermittent stream (Own elaboration)

$A=$ Interception factor due to rain (\%); Exponent values

$a=0.05 ; b=1$

$G=\mathrm{CQ}^{d} \operatorname{sen} S \cdot 10^{-3}$ where $G=$ Surface flow transport capacity $(\mathrm{kg} / \mathrm{m} 2)$, $C=$ Vegetation factor, $Q=$ Volume of superficial flow $(\mathrm{mm})$, 
Table 2 Parameters for estimating soil losses according to the MMF erosion model (Morgan, [73]

\begin{tabular}{lllll}
\hline Characteristics & \multicolumn{2}{l}{ Parameters } & \multicolumn{2}{l}{ Source } \\
\hline Soil types & MS & BD & $K$ & Figure. 5 \\
Ferralitic & 0.45 & 1.10 & 0.02 & Source: Table 6.5 in Morgan [72] \\
Brown & 0.20 & 1.30 & 0.30 & \\
Humic Calciorphic & 0.45 & 1.10 & 0.02 & \\
Land Use & Un & $E_{\mathrm{T} /} E_{0}$ & $C$ & Figure. 5 \\
Temporary crops & 17.00 & 0.80 & 0.40 & Source: Table 6.11 in Morgan [72] \\
Permanent crops & 25.00 & 0.66 & 0.40 & \\
Sugar cane & 25.00 & 0.74 & 0.20 & \\
Pasture & 25.00 & 0.80 & 0.001 & \\
Forest & 25.00 & 0.90 & 0.001 & \\
Idle lands & 25.00 & 0.80 & 0.001 & \\
Unsuitable land, watery & 100.00 & 1.35 & 0.10 & \\
Other unsuitable land & 25.00 & 0.80 & 0.001 & \\
Climatic & & & & \\
$\quad$ Number of windy days & 119 & & & Llacer [67] \\
The intensity of rainfall (mm $\mathrm{h}^{-1}$ ) & 25 & & & Morgan [71] \\
Annual rainfall accumulation (mm) & Figure. & & & \\
\hline
\end{tabular}

The final prediction of the soil loss is made by comparing the values obtained of $G$ and $F$. The lower of they are take like annual loss rate of soil.

For the estimation of nutrient losses, the assumption was made that the basin discharges by a single sector into the sea. Equation (7) with slight modifications (Eq. 8) was used to estimate the effects of the amount of nutrients and sediments coming from the upper part of the basin through 13 small sub-basins that were mapped (Fig. 1).

$\mathrm{NE}=\sum_{i=1}^{n} \frac{\mathrm{SV}_{i} \cdot \mathrm{dBD}_{i} \cdot \mathrm{NC}_{i}}{10 \cdot n \cdot A \cdot \mathrm{NTE}}$

$\mathrm{NE}_{i}=\frac{\left(\left(\sum_{i=1}^{n} \mathrm{SV}_{i} \cdot \mathrm{dBD}_{i} \cdot \mathrm{NC}_{i}\right)+\left(\mathrm{SV}_{i-1} \cdot \mathrm{dBD}_{i-1} \cdot \mathrm{NC}_{i-1}\right)\right)}{10 \cdot n \cdot A \cdot \mathrm{NTE}}$

$\mathrm{SV}_{i-1}=\mathrm{SV}_{\text {upperbasin }} * \mathrm{NTE}_{\text {upperbasin }}$

$\mathrm{NCi}_{i-1}=\frac{\mathrm{NE}_{i-1} \cdot 10^{6}}{d \cdot \rho}$

where NE: Nutrient exportation $\left(\mathrm{kg} \mathrm{ha}^{-1} \mathrm{yr}^{-1}\right)$; SV: Volume of sediment moved $\left(\mathrm{m}^{3} \mathrm{yr}^{-1}\right), \mathrm{dBDi} i$ : Density of soil in sample $i\left(\mathrm{Mg} \mathrm{m}^{-3}\right), \mathrm{NCi}$ : Nutrient content associated with the sediment in the sample $i$ (ppm), NTE: Efficiency of the nutrient trap in the basin (\%), $A$ : Basin area (ha), $\mathrm{SV}_{i-1}$ : Amount of sediment from the upper basin $(\mathrm{t}), \mathrm{NCi}_{i-1}$ : Amount of the nutrient from the upper basin (ppm), $d$ : Depth of soil (m), $\rho$ : Density of soil $\left(\mathrm{mg} \mathrm{kg}^{-1}\right), \mathrm{dBDi}_{i-1}$ : Soil density of the upper basin $\left(\mathrm{Mg} \mathrm{m}^{-3}\right), \mathrm{NE}_{i-1}$ : Exporting nutrients from the upper basin $\left(\mathrm{kg} \mathrm{ha}^{-1} \mathrm{yr}^{-1}\right)$.
The parameters for running the equation are shown in Table 3.

\section{Results and discussion}

\subsection{Erosion estimation}

The estimated average annual erosion was $0.6 \pm 0.1$ (t ha ${ }^{-1}$ ), classified as very low according to Geler [37], with the transport capacity of the surface flow being the limiting factor for erosion. The low rates are the result of a gentle slope and the mechanical composition of the soils is predominantly clay (85\%), which has a high degree of resistance to detachment by the drop of rain, results that are consistent with De Ploey [18], Poesen [83] in similar soils.

In addition, the plant cover acts as a buffer between the atmosphere and the soil. The highest erosion rates were estimated in the crop sectors ( $\min 0.04-\max 0.89$, mean $0.1 \mathrm{~kg} \mathrm{~m}^{-2} \mathrm{yr}^{-1}$ ), both in short and long periods (Fig. 6). These can produce a fleeting runoff by increasing the size of the raindrops on their leaves; these can achieve water accumulations at the drip points, capable of producing accumulations that can eventually overcome the infiltration capacity $[4,17,50]$. According to an effect that could be verified in the intensive and continuous use of the soils with almost permanent predominance of multiple crops, promotes the detachment and the areal migration of the finest fractions, at a rate directly related to the energetic speeds of the raindrops, 
Table 3 Parameters for the estimation of nutrient export according to the equation of Verstraeten and Poesen (99)

\begin{tabular}{|c|c|c|c|c|c|c|c|c|}
\hline \multirow{3}{*}{$\begin{array}{l}\text { Parameters } \\
\mathrm{NCi}\end{array}$} & \multicolumn{8}{|l|}{ Values } \\
\hline & Soils & $K$ & $P$ & $d$ & $\rho$ & Source & $N$ & Source \\
\hline & & (ppr & & $\mathrm{m}$ & $\mathrm{g} \mathrm{cm}^{-}$ & & $\%$ & \\
\hline & Ferralitic & 20 & 21.2 & 0.7 & 1.32 & \multirow{3}{*}{$\begin{array}{l}\text { Source: Table of attributes of } \\
\text { Soil Map 1: } 500000 \text { (Tremols } \\
\text { and Hernandez, 2006) }\end{array}$} & 0.25 & $\begin{array}{l}\text { INRA (1975); } \\
\text { Soca Nuñez, (2017) }\end{array}$ \\
\hline & Brown & 29 & 6.9 & 0.3 & 1 & & 0.14 & $\begin{array}{l}\text { Espinosa (2015); } \\
\text { Soca Nuñez, (2017) }\end{array}$ \\
\hline & Humic Calciorphic & 30 & 32.0 & 0.3 & 1.1 & & 0.18 & INRA, 1975 \\
\hline $\mathrm{SV} \cdot \mathrm{dBDi}=$ Soil loss in tons & \multicolumn{8}{|c|}{$\operatorname{MMF}_{\text {mediadelasubcuencai }}\left(t \cdot \mathrm{ha}^{-1}\right) \cdot A_{\text {subcuencai }}(\mathrm{ha})=$ soil loss in tons of the sub - basin } \\
\hline NTE & \multicolumn{8}{|c|}{$\begin{array}{l}\text { Estimated by the methodology proposed by Verstraeten and Poesen [99] through the sediment trap model } \\
\text { proposed by Verstraeten and Poesen [98] }\end{array}$} \\
\hline
\end{tabular}

Fig. 6 Soil erosion rate of La Teresa karstic basin in the Southern Havana-Matanzas Karstic Plain, Cuba
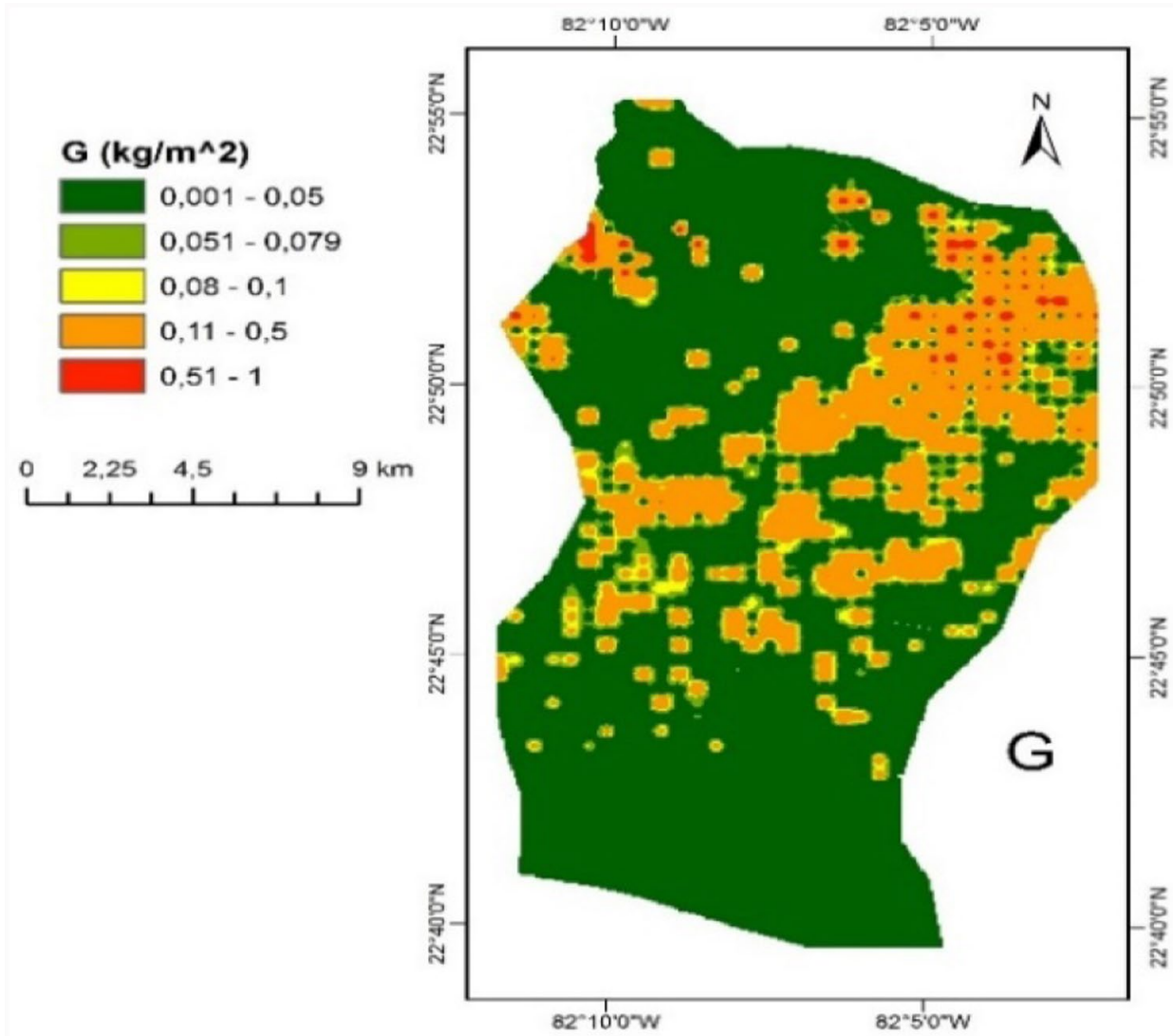

originating a sequential descent of the solum towards the concave flexions of the micro-relief that act as local base levels [28].

The areas of pasture $(\min 0.01-\max 1.01$, mean $0.04 \mathrm{~kg} \mathrm{~m}^{-2} \mathrm{yr}^{-1}$ ) and forest ( $\min 0.001-\max 0.82$, mean $0.03 \mathrm{~kg} \mathrm{~m}^{-2} \mathrm{yr}^{-1}$ ) present lower values than the crops, because they have a low level of tillage, which gives them a high degree of roughness and decreases the speed of surface flow, which is strongly determined by the morphology and density of the plants [85]. In forest areas, the root network not only influences roughness, but also provides effective soil retention [10].

Another element that influences the low erosion values are the karstic canyons with valleys in the shape of " $U$ " and " $V$ " that act as geomorphological barriers transversally to the slopes, which intercept the runoff, as well as the 
erosion of the soils that transport the nutrients; this causes the redistribution of the nutrients in the basin (Fig. 1). This "regulating" effect of surface flow is a basic element of the hydrographic fabric in the Southern Havana-Matanzas Karstic Plain, where the forms of absorption and its component elements exercise control over surface and subsurface drainage on their way to the sea, which coincides with the descriptions of Fernández de Valderrama [31] and Febles et al. [24].

Fig. $7 N, P, K$ values exported from La Teresa karstic basin, Mayabeque Province

\subsection{Estimation of the export of nutrients in the basin}

The highest export rates in the basin (Fig. 7) were recorded in those sectors occupied by crops in soils with a clayey texture (Fig. 3), coinciding with the most eroded sectors (Fig. 6). Being those of the sub-basins No. 6 and 10 the highest (Table 4).

In fact, a spatial-zonal pattern can be distinguished in the export of nutrients, with low values in the upper

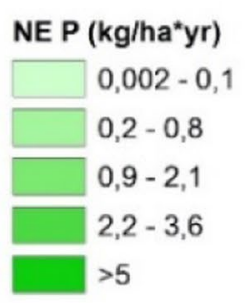

NE K (kg/ha*yr)

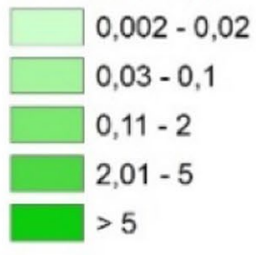

NTE $(\%)$
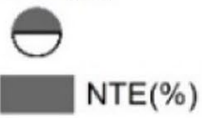

$N$
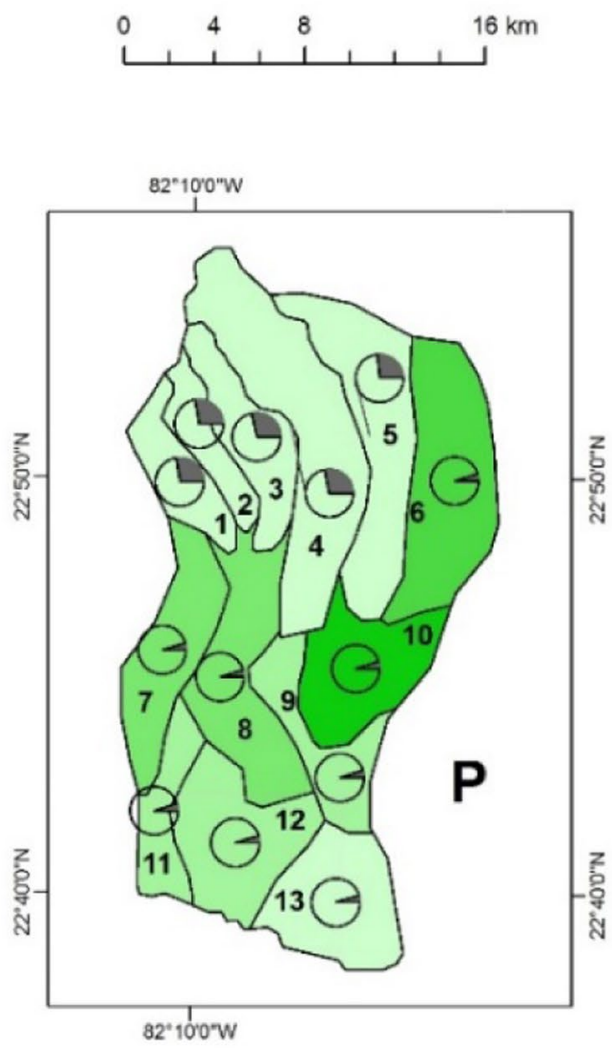

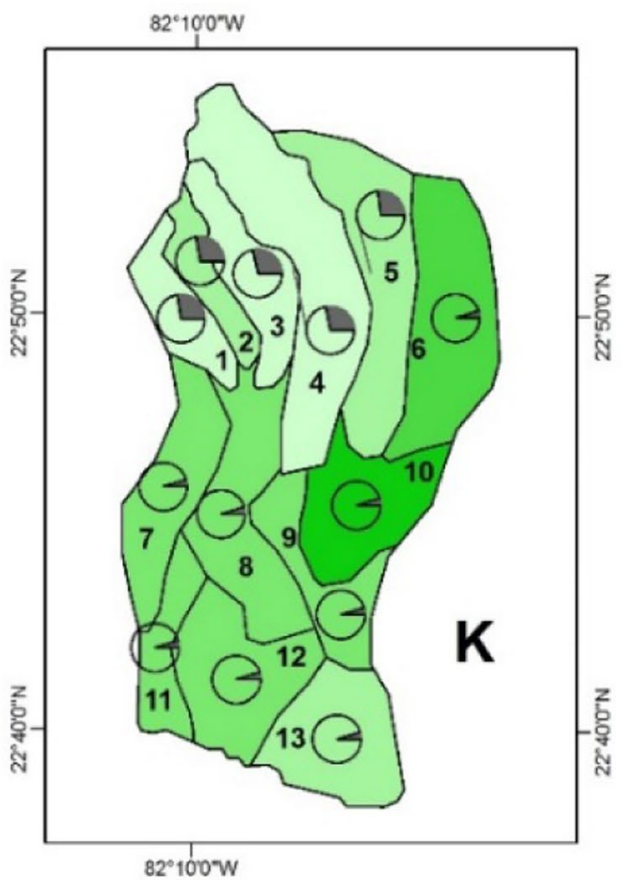

$82^{\circ} 100 \mathrm{~W}$

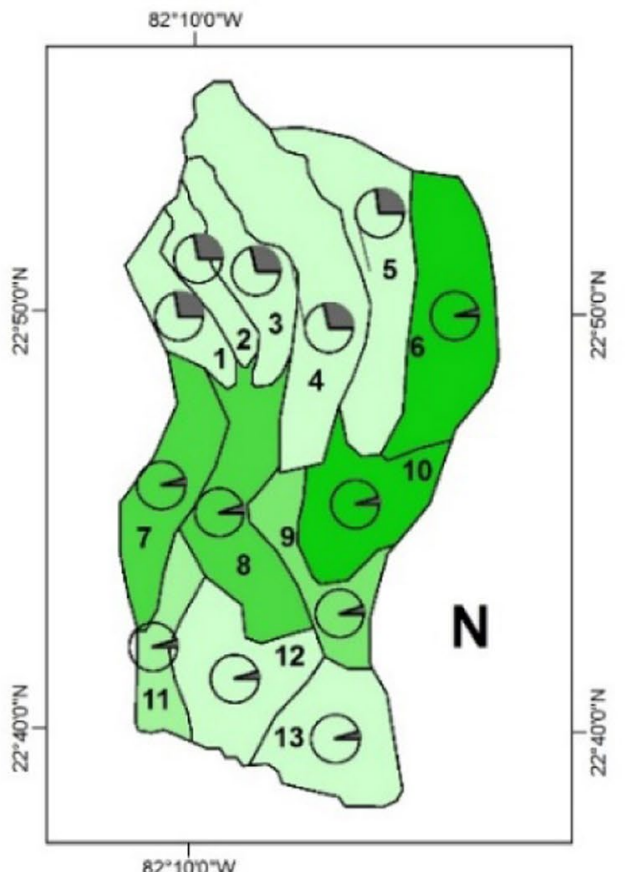

$82^{\circ} 100{ }^{\circ} \mathrm{W}$ 
Table 4 Estimated nutrient export values for each subbasin

\begin{tabular}{llllllllll}
\hline $\begin{array}{l}\text { Sub } \\
\text { basin }\end{array}$ & $\begin{array}{l}\text { Area } \\
\left(\mathrm{m}^{2} 10^{6}\right)\end{array}$ & $\begin{array}{l}G \\
\left(\mathrm{~kg} \mathrm{~m}^{-2}\right)\end{array}$ & $\begin{array}{l}\text { NTE } \\
(\%)\end{array}$ & $\begin{array}{l}K \\
(\mathrm{ppm})\end{array}$ & $\begin{array}{l}\mathrm{N} \\
\%\end{array}$ & $\begin{array}{l}\text { NE } K \\
\left(\mathrm{~kg} \mathrm{ha}^{-} \mathrm{yr}^{-1}\right)\end{array}$ & $\mathrm{NE}$ & $\mathrm{NEN}$ \\
\hline 1 & 14.87 & $0.05 \pm 0.01$ & 38.70 & 23.41 & 18.24 & 0.22 & $0.03 \pm 0.05$ & $0.02 \pm 0.03$ & $1.51 \pm 0.04$ \\
2 & 11.52 & $0.09 \pm 0.01$ & 38.65 & 24.98 & 14.13 & 0.19 & $0.03 \pm 0.01$ & $0.02 \pm 0.03$ & $2.15 \pm 0.01$ \\
3 & 20.67 & $0.01 \pm 0.02$ & 39.83 & 24.92 & 14.76 & 0.19 & $0.004 \pm 0.03$ & $0.002 \pm 0.02$ & $0.26 \pm 0.03$ \\
4 & 54.01 & $0.04 \pm 0.06$ & 39.14 & 25.26 & 15.68 & 0.20 & $0.02 \pm 0.20$ & $0.01 \pm 0.20$ & $1.08 \pm 0.3$ \\
5 & 38.86 & $0.11 \pm 0.02$ & 36.97 & 22.61 & 18.72 & 0.22 & $0.22 \pm 0.01$ & $0.03 \pm 0.04$ & $2.28 \pm 0.01$ \\
6 & 40.70 & $0.16 \pm 0.03$ & 1.00 & 21.30 & 23.24 & 0.25 & $3.34 \pm 1.00$ & $3.65 \pm 1.00$ & $77.6 \pm 1.00$ \\
7 & 26.43 & $0.06 \pm 0.01$ & 1.00 & 19.00 & 21.71 & 0.25 & $0.25 \pm 1.00$ & $1.22 \pm 1.00$ & $27.7 \pm 1.00$ \\
8 & 34.14 & $0.05 \pm 0.01$ & 1.00 & 19.16 & 21.82 & 0.25 & $1.86 \pm 0.30$ & $2.12 \pm 0.34$ & $25.65 \pm 1.00$ \\
9 & 19.19 & $0.03 \pm 0.01$ & 1.00 & 19.46 & 22.11 & 0.25 & $0.27 \pm 0.04$ & $0.31 \pm 0.1$ & $11.14 \pm 0.10$ \\
10 & 27.68 & $0.05 \pm 0.01$ & 1.00 & 19.26 & 21.89 & 0.25 & $5.56 \pm 0.10$ & $6.31 \pm 0.13$ & $52.4 \pm 0.20$ \\
11 & 13.96 & $0.01 \pm 0.02$ & 1.00 & 23.35 & 25.79 & 0.22 & $0.49 \pm 0.1$ & $0.54 \pm 0.1$ & $6.02 \pm 0.10$ \\
12 & 31.14 & $0.01 \pm 0.02$ & 1.00 & 25.41 & 27.73 & 0.21 & $0.72 \pm 0.1$ & $0.78 \pm 0.1$ & $2.53 \pm 0.10$ \\
13 & 28.83 & $0.01 \pm 0.02$ & 1.00 & 29.92 & 31.96 & 0.18 & $0.06 \pm 0.01$ & $0.06 \pm 0.01$ & $0.96 \pm 0.02$ \\
\hline
\end{tabular}

part, high values in the middle sector and again another decrease in the lower sector of the basin. This in the upper sector is associated with the coarser texture type of Brown soils, which causes the effectiveness of sediment traps to be superior to those with clayey texture and in the lower sector, the cause is the low geomorphic potential of the slopes near the coast to be able to move the particles (Fig. 7 and Table 4).

The behaviors of the traps in the sub-basins 6 to 13 are low, due to the mechanical composition of the soils, which are mainly of a clayey texture (Red Ferrallitic and Humic Calcimorphic), since the fractions with diameters $<0.01 \mathrm{~mm}$ require more energy to be suspended [62], but once suspended, they will only require weak flows for their transport and the weaker these are the finer the fractions $[19,51]$.

Therefore, this fraction does not sediment until it reaches the sea, as the salts act as a weak electrolyte and precipitates them, corroborating the results obtained by Hjulstrom [51], Derruau [19] and Febles et al. [24]. This fraction has a colloidal character, so the amount of nutrients lost with it is higher than the other texture. Which shows that not necessarily where the highest rate of erosion exists, is where the highest rates of nutrient export may exist.

\subsection{Influence of soil erosion on the waters of the Gulf of Batabanó}

The export of nutrients such as nitrogen and phosphorus to the Gulf of Batabanó (Table 5) can be classified as low when compared to other studies (Table 6), only the study by Yue et al. [102] was developed in karst regions, their estimates were in groundwater drainage conditions, the only surface area was a river, not in basins with
Table 5 Total nutrients exported to the sea by La Teresa karstic basin, Mayabeque Province

\begin{tabular}{lllll}
\hline Variables & $P(\mathrm{t})$ & $\begin{array}{l}P \\
\left(\mathrm{~kg} \mathrm{ha}^{-1} \mathrm{yr}^{-1}\right)\end{array}$ & $N(\mathrm{t})$ & $\begin{array}{l}N \\
\left(\mathrm{~kg} \mathrm{ha}^{-1} \mathrm{yr}^{-1}\right)\end{array}$ \\
\hline Values & $2.3 \pm 0.4$ & $0.064 \pm 0.01$ & $35 \pm 0.02$ & $1.0 \pm 0.02$ \\
\hline
\end{tabular}

intermittent drainage as in the present study. These low values are a consequence of the natural physical-geographical characteristics of the basin, whose effects are the low erosion values. Not because of the nutrient content (Table 4), since Ferralitic and Humic Calcimorphic soils which present moderate (10-17 ppm), high (17-25 ppm) and very high $(<25 \mathrm{ppm})$ phosphorus values $[48,52]$ and medium (0.14-0.25\%) nitrogen values[11, 48].

The waters of the Gulf of Batabanó are oligotrophic waters (Montalvo, 2010; [41] under strong historical pressure. This is product of the execution of various hydrotechnical works during the 1970 s (damming) for the development of agricultural programs $[6,70]$, in which the Dique Sur [South Dike] stands out, these actions have had a notable influence on the contributions of nitrogen from the land, by acting as barriers to the waters that previously discharged into the sea, together with the drastic reduction in fertilizer imports during the so-called Special Period in Cuba (1991-1996)[7, 26].

The reduced amount of nutrients reaching the sea from the land (Table 5), due to the low geomorphic potential for runoff typical of a karst plain plus the effects of engineering works built along the plain (dams), has resulted in a further decrease in the natural speed of biogeochemical cycles. Results that are in agreement with those of Baisre $[5,6]$, Claro et al. [14] on the decrease of total biomass and size of fish in the golf from the early 90 s coinciding with 
Table 6 Export nitrogen and phosphorus values ( taken from Iverson et al. [59] and updated by the authors)

\begin{tabular}{|c|c|c|c|}
\hline Author & Place & $\begin{array}{l}N \\
\left(\mathrm{~kg} \mathrm{yr}^{-1} \mathrm{ha}^{-1}\right)\end{array}$ & $\begin{array}{l}P \\
\left(\mathrm{~kg} \mathrm{yr}^{-1} \mathrm{ha}^{-1}\right)\end{array}$ \\
\hline Iverson et al. [60] & North Carolina Coastal Plain & $0.3-13$ & - \\
\hline Line [43] & North Carolina Piedmont & $1.92-6.65$ & $0.01-0.14$ \\
\hline $\begin{array}{l}\text { Withers et al. [100] } \\
\text { Upstream of Septic } \\
\text { Downstream of Septic }\end{array}$ & $\begin{array}{l}\text { Loddington, Leicestershire, } \\
\text { UK }\end{array}$ & $\begin{array}{l}14.07 \\
17.25\end{array}$ & $\begin{array}{l}0.16 \\
0.26\end{array}$ \\
\hline NC DENR [76] & North Carolina Piedmont & $1.8-14.4$ & $0.2-0.3$ \\
\hline Shields et al. [88] & Maryland Piedmont & 6.0 & - \\
\hline Groffman et al. [45] & & $4.5-7.2$ & - \\
\hline Castro et al. [12] & Various basins in USA & $11.7(1.9-41.9)$ & - \\
\hline $\begin{array}{l}\text { Oblinger et al. [79] } \\
\text { Forested } \\
\text { Mixed agricultural } \\
\text { Mixed residential }\end{array}$ & North Carolina Piedmont & $\begin{array}{l}2.22 \\
3.15-5.25 \\
0.73-2.17\end{array}$ & $\begin{array}{l}0.08 \\
0.16-0.52 \\
0.27-0.81\end{array}$ \\
\hline Nikolaidis et al. [77] & Connecticut New England & 3.6 (nitrate) & - \\
\hline Valiela et al. [94] & Massachusetts Coastal Plain & 2.2 & - \\
\hline $\begin{array}{l}\text { Iverson et al. [59] } \\
\text { High-density (input significant nutri- } \\
\text { ents to receiving waters) } \\
\text { Low density (not input significant nutri- } \\
\text { ents to receiving waters) }\end{array}$ & Durham country & $\begin{array}{l}4.1(0.01-44.1) \\
1.5(0.0-35.3)\end{array}$ & $\begin{array}{l}0.15(0.0-1.9) \\
<0.1(0.0-0.8)\end{array}$ \\
\hline Ferreira et al. [32] & São Lourenço (Portugal) & $1.3-10.8$ & $0.5-3.6$ \\
\hline $\begin{array}{l}\text { Napoli et al. [75] } \\
\text { In grass plot (vineyard) } \\
\text { In harrowed plot(vineyard) }\end{array}$ & Central Italy & $\begin{array}{l}4.5 \\
12.5\end{array}$ & $\begin{array}{l}6.2 \\
5.0\end{array}$ \\
\hline Ramos et al. (2006) (vineyard) & Penedès region (NE Spain) & 14.9 & 11.5 \\
\hline $\begin{array}{l}\text { Vadas and Powell [93] } \\
\text { Vegetated (in dairy cattle lots) } \\
\text { Partially vegetated } \\
\text { Unvegetated (in dairy cattle lots) } \\
\text { Corn silage (in dairy cattle lots) }\end{array}$ & Farms in Wisconsin & $\begin{array}{l}10.2 \\
29.2 \\
46.6 \\
59.9\end{array}$ & $\begin{array}{l}2.9 \\
6.8 \\
116 \\
100\end{array}$ \\
\hline $\begin{array}{l}\text { Yue et al., [102] (karst environment) } \\
\text { Houzhai River (river) } \\
\text { Maoshuikeng (groundwater and surface) }\end{array}$ & $\begin{array}{l}\text { Houzhai Catchment } \\
\text { (Guizhou Province, SW } \\
\text { China) }\end{array}$ & $\begin{array}{l}7.5 \\
14.7\end{array}$ & - \\
\hline Average & & 11.41 & $2.05^{*}$ \\
\hline
\end{tabular}

*The values of Vadas and Powell were not taken into account because they are extreme values the completion of the southern dam (1985-1991) [46] and the conclusion of the last dam in 1991 [8]. This reduction in biomass is produced by the drastic decrease of landbased nutrient inputs to the marine platform, generating food deprivation, which leads to alterations in the food chain $[7,8,39]$, indicating that the system is under strong stress. This stress also affects the fishing communities that depend on these marine resources.

Because of this, the adoption of measures that further reduce soil erosion in the basin would limit the inputs of nutrients or the speed of their cycles; which implies increasing the pressure on the aquatic ecosystems of the Gulf of Batabanó, where important economic resources and populations dependent on them converge. Therefore, a management alternative to be considered, without exerting additional pressure on these peculiar ecosystems, would be the appropriate management of gramineae (sugar cane, saccharum officinarum) as these are very demanding of Nitrogen, the planting of leguminous plants, green fertilizers (crotalaria juncea, dolichos pruriens), worm farming, mulching, waste returns, and any source of organic fertilizer that is decomposed and provides the soils with nitrogen and organic phosphate. These measures will also promote the increase of organic matter in the soil and increase the availability of phosphorus to the crops by reducing the tendency of the mineral fraction to fix the nutrients; for this reason, it is difficult to know if the increase of phosphorus will increase the export of it to the platform. 


\section{Conclusion}

The influence of soil erosion in the karstic basin of La Teresa has a dual character, beneficial for the soil resource due to the low erosion and loss of nutrients, but it does not foresee improvements for the stress suffered by the marine resources due to its historical reduction of nutrients. This export of nutrients from the basin is regulated, after erosion, by the texture of the soils, as this is the cause of the low values of the nutrient traps. These factors cause the rates of export of nutrients from the soil to the sea to be low with input levels of $0.064 \mathrm{~kg} \mathrm{ha}-1 \mathrm{yr}-1$ (2.3 t) of $P, 1 \mathrm{~kg}$ ha-1 yr-1 (35 t) of $\mathrm{N}$ and $0.06 \mathrm{~kg} \mathrm{ha}-1 \mathrm{yr}-1$ (2.1 t) of $K$. These estimates provide a rough quantitative idea of the region's geomorphic potential, which explains the changes that have taken place in the past and can be used to predict those that will take place in the future. The use of this methodology, in all the basins that drain into the gulf, with more detailed data on land use and in a seasonal manner, would make possible a more holistic framework for the integrated management of natural resources by being able to analyze their relationship with marine currents, spawning sites, fishing seasons and closures, etc.

\section{Compliance with ethical standards}

Conflict of interest On behalf of all authors, the corresponding author states that there is no conflict of interest.

\section{References}

1. Akrasi SA, Ansa-Asare OD (2008) Assessing sediment and nutrient transport in the Pra Basin of Ghana. West Afr J Appl Ecol 13(1):45-54

2. Álvarez-Cobelas M, Angeler DG (2007) Exportación de nutrientes en las cuencas hidrográficas de Latinoamérica: una recopilación. Rev Latinoam Recur Nat 3(1):31-43

3. Al-Wadaey A, Ziadat F (2014) A participatory GIS approach to identify critical land degradation areas and prioritize soil conservation for mountainous olive groves-case study. J Mt Sci 11(3):782-791

4. Armstrong CL, Mitchell JK (1987) Transformations of rainfall by plant canopy. Trans Am Soc Agric Eng 30(3):688-0696

5. Baisre J (1995) Chronicle of Cuban marine fisheries (19351995). Trend analysis and fisheries potential. Food and Agriculture Organization

6. Baisre JA (2004) La pesca marítima en Cuba. La Habana. Científico-Técnica, Cuba

7. Baisre JA (2006) Assessment of nitrogen flows into the Cuban landscape. Biogeochemistry 79:91-108

8. Baisre JA, Arboleya Z (2006) Going against the flow: effects of river damming in Cuban fisheries. Fish Res 81:283-292

9. Betanzos-Vega A, Capetillo-Piñar N, Lopeztegui-Castillo A, Garcés-Rodríguez Y, Tripp-Quezada A (2019) Parámetros meteorológicos, represamiento fluvial y huracanes. Variaciones en la hidrología del golfo de Batabanó Cuba. Rev Biol Mar Oceanogr 54:308-318

10. BronickLal CJR (2005) Soil structure and management: a review. Geoderma 124:3-22

11. Bruce R, Rayment G (1982) Analytical methods and interpretations used by the agricultural chemistry branch for soil and land use surveys. Bulletin QB8 (2004). Queensland Department of Primary Industries, Indooroopilly, Queensland

12. Castro M, Driscoll C, Jordan T, Reay W, Boynton W (2003) Sources of nitrogen to estuaries in the United States. Estuaries 26:803-814

13. Ceruto OA, Hurtado EG, Miranda GD, Betancourt AC (2018) Talla de primera maduración del cangrejo moro, Menippe mercenaria (Say, 1818), en el golfo de Batabanó Cuba. Ser Oceanol 14:58-67

14. Claro R, Baisre J, Lindeman K, García-Arteaga J (2001) Cuban fisheries: historical trends and current status. En Ecol Mar Fishes Cuba (págs. 194-219). Smithsonian Institution Press, Washington

15. Dahal G, Holcomb J, Socci D (2011) Surfactantoxidation coapplication for soil and groundwater remediation. Remediat J 26:101-108

16. de la Guardia E, Giménez-Hurtado E, Defeo O, Angulo-Valdes J, Hernández-González Z, Espinosa-Pantoja L, Arias-González JE (2018) Indicators of overfishing of snapper (Lutjanidae) populations on the southwest shelf of Cuba. Ocean Coast Manag 153:116-123

17. De Ploey J (1982) A stemflow equation for grasses and similar vegetation. CATENA 9(1-2):139-152

18. De Ploey J, Mücher HJ (1981) A consistency index and rainwash mechanisms on Belgian loamy soils. Earth Surf Proc Land 6(3-4):319-330

19. Derruau M (1991). Geomorfologia

20. Dirección Nacional de Suelos y Fertilizantes (INRA) (1975). Suelos de Cuba (Vol. Tomo I). La Habana, Orbe

21. Espinosa A, Ruiz L, Rivera R, Espinosa E (2015) Nitrogen and arbuscular mycorrhizal fungi (AMF) effect on two commercial sweet potato clones on an inseptisol soil. Cent Agrícola 42:39-46

22. FAO. (1979). A provisional methodology for soil degradation assessment. Roma

23. Farina JM, Salazar S, Wallem KP, Witman JD, Ellis JC (2003). Nutrient exchanges between marine and terrestrial ecosystems: the case of the Galapagos sea lion Zalophus wollebaecki. J Anim Ecol 873-887

24. Febles JM, Pacheco MA, Castro I. y Jerez L (2005) Creación de una red deindicadores de sostenibilidad en áreas rurales de La Habana. Primer año de resultados [unpublished], Universidad Agraria de La Habana

25. Febles Díaz JM, Vega MB (2016) Estimación del aporte de la erosión hídrica al azolve del embalse Mampostón. Ing Hidrául Ambient 37:18-30

26. Febles González JM, Tolón Becerra A, Lastra Bravo X, Acosta Valdés X (2011) Cuban agricultural policy in the last 25 years From conventional to organic agriculture. Land Use Policy 28(4):723-735

27. Febles González JM, Vega Carreño MB, Tolón Becerra A, Lastra Bravo X (2012) Assessment of soil erosion in karst regions of Havana Cuba. Land Degrad Dev 23(5):465-474. https://doi. org/10.1002/ldr.1089

28. Febles González JM, Vega M, Do Amaral-Sobrinho NM (2014) Relation among the processes of erosion: sedimentation-pollution in soils from the Distrito Pecuario "Alturas de Nazareno" Cuba. J Agric Sci 48(2):173-179

29. Febles González JM, Vega M, Do Amaral-Sobrinho NM, Tolón A, Lastra-Bravo XB (2014) Good soils in extinction: Degradation 
of red ferralitic soils in western Cuba. Soil Sci. https://doi. org/10.1097/SS.0000000000000070

30. Fernández de Ortega I (2007) Hidrogeología de las sierras de badaia y arkamo (U.H. Calizas de Subijana, País Vasco). Tesis Doctoral, Universidad del País Vasco-Euskal Herriko Unibertsitatea, Dpto de Geodinámica

31. Fernández de Valderrama I (2004) Contribución al estudio hidrogeológico de la Unidad Kárstica de Santa Eufemia-Ereñozar (zona nororiental de Bizkaia). Aportación de los ensayos con trazadores al conocimiento del medio kárstico. Tesis Doctoral, Universidad del País Vasco-Euskal Herriko Unibertsitatea, Departamento de Geodinámica

32. Ferreira CS, Keizer JJ, Santos LM, Serpa D, Silva V, Cerqueira M, Abrantes N (2018) Runoff, sediment and nutrient exports from a Mediterranean vineyard under integrated production: an experiment at plot scale. Agric Ecosyst Environ 256:184-193

33. Ford D, Williams PD (2013) Karst hydrogeology and geomorphology. Wiley, Hoboken

34. Galloway J, Dentener F, Boyer E, Howarth R, Seitzinger S, Asner G, Green P (2004) Nitrogen cycles: past, present, and future. Biogeochemistry 70:153-226

35. Gao H, Li Z, Li P, Jia L, Zhang X (2012) Quantitative study on influences of terraced field construction and check-dam siltation on soil erosion. J Geogr 22:946-960

36. García-Machado E, Ulmo-Díaz G, Castellanos-Gell J, Casane D (2018) Patterns of population connectivity in marine organisms of Cuba. Bull Mar Sci 94(2):193-211

37. Geler T (2000) Prediction soil erosion hazards caused by lands use changes. MSc. Thesis, Wageningen University and International Institute for Aerospace Survey and Earth Sciences, Centre for Geo-information, Wageningen

38. Ghosal S, Rogers M, Wray A (2000) The turbulent life of phytoplankton

39. Gómez SC, Fadragas OM, Millán RP, Soto RP, de León González ME (2015) La sustentabilidad en la pesquería de la langosta espinosa (Panulirus argus) en el golfo de Batabanó, Cuba. II. Indicadores multidimensionales. Rev Cubana Investig Pesq

40. González JA (1994) Comportamiento de variables hidroquímicas en los principales esteros en la zona camaronera de Playa Florida 1986-1990. Rev Investig Pesq 18:1-6

41. González-De Zayas R, González JA, Merino-Ibarra M, Sandoval FS (2014) Condiciones hidroquímicas recientes de la zona central del golfo de Ana María, Cuba/Recent Hydrochemical conditions at central zone of Ana Maria gulf Cuba. Rev Investig Mar 32(2):9-14

42. Gonzalez-Sanson GC, Aguilar I, Hernandez Y, Cabrera Y, Curry R (2009) The influence of habitat and fishing on reef fish assemblages in Cuba. Gulf Caribb Res 21:13-21

43. Gounou E, Febles JM (1997) Aplicación del enfoquemorfoedafológico al estudio de la variabilidad de algunossuelos en un geosistema cársico. PhD Thesis, Universidad Agraria de La Habana «Fructuoso Rodríguez Pérez», Havana

44. Grimvall A, Stålnacke P, Tonderski A (2000) Time scales of nutrient losses from land to sea-a European perspective. Ecol Eng 14:363-371

45. Groffman P, Law N, Belt K, Band L, Fisher G (2004) Nitrogen fluxes and retention in urban watershed ecosystems. Ecosystems 7(4):393-403

46. Guevara AV, Campos A, León A, Vega R (2004) El dique sur de La Habana (Cuba) y su influencia en el comportamiento de elementos climaticos seleccionados. Rev Cuba Meteorol

47. Hartmann A, Goldscheider N, Wagener T, Lange J, Weiler M (2014) Karst water resources in a changing world: review of hydrological modeling approaches. Rev Geophys 52:218-242

48. Hazelton P, Murphy B (2016) Interpreting soil test results: what do all the numbers mean? CSIRO publishing, Clayton
49. Herrero JE (2003) Fajas forestales hidrerreguladoras. Agrinfor Ministerio de la agricultura, La habana

50. Herwitz SR (1986) Infiltration-excess caused by stemflow in a cyclone-prone tropical rainforest. Earth Surf Proc Land 11(4):401-412

51. Hjulstrom $F$ (1935) Studies of the morphological activity of rivers as illustrated by the River Fyris. Bull Geol Inst Upsalsa 25:221-527

52. Holford IC, Cullis BR (1985) Effects of phosphate buffer capacity on yield response curvature and fertilizer requirements of wheat in relation to soil phosphate tests. Soil Res 23:417-427

53. Horton R (1932) Drainage basin characteristics. Am Geophys Union 13:350-361

54. Huttunen I, Lehtonen $H$, Huttunen M, Piirainen V, Korppoo M, Veijalainen N, Vehviläinen B (2015) Effects of climate change and agricultural adaptation on nutrient loading from Finnish catchments to the Baltic Sea. Sci Total Environ 529:168-181

55. IGP (2013) Léxico estratigráfico de Cuba. Servicio geológico de Cuba

56. INRH (2015) Pluviómetros de la región occidental de Cuba. La Habana

57. ITPS (2015) Status of the World's Soil Resources. Prepared by Intergovernmental Technical Panel on Soils (ITPS) for the Food and Agriculture Organization of the United Nations (FAO), Rome

58. IUCN (2017) Red list of threatened species. Obtenido de International Union for Conservation of Nature and Natural Resources. www.iucnredlist.org

59. Iverson G, Humphrey C Jr, O'Driscoll M, Sanderford C, Jernigan $J$, Serozi B (2018) Nutrient exports from watersheds with varying septic system densities in the North Carolina Piedmont. J Environ Manag. https://doi.org/10.1016/j.jenvman.2018.01.063

60. Iverson G, O'Driscoll MA, Humphrey C, Manda A, AndersonEvans E (2015) Wastewater nitrogen contributions to coastal plain watersheds, NC. Water Air Soil Pollution, USA

61. Kiersch B (2000). Land-water linkage in rural watersheds. Bol Tierras Aguas

62. Kjaergaard C, De Jonge LW, Moldrup P, Schjønning P (2004) Water-dispersible colloids: effects of measurement method, clay content, initial soil matric potential, and wetting rate. Vadose Zone J 3:403-412

63. Kresic N, Stevanovic Z (2009) Groundwater hydrology of springs: engineering, theory, management and sustainability. Butterworth-heinema

64. Leal Z, Díaz J, Schiettecatte W, Ruiz ME, Almoza Y (2007) Efecto de la cobertura vegetal de cultivos agrícolas principales sobre el proceso de erosión en suelos de la cuenca del río Cuyaguateje. Rev Cienc Téc Agropecu 16:76-83

65. Likens G, Bormann F, Pierce R, Eaton J, Johnson N (1977) Biogeochemistry of a forested ecosystem. Springer Verlag, New York

66. Line D (2013) Effect of development on water quality for seven streams in North Carolina. Environ Monit Assess. https://doi. org/10.1007/s10661-012-3024-z

67. Llacer ID (2016) Cantidad de días con lluvia y su distribución por intervalos en condiciones normales y de sequía severa en el occidente de Cuba. Rev Cuba Meteorol 22(1):49-65

68. Menéndez Carrera LM (2013) El ecosistema de manglar en el archipiélago cubano: bases para su gestión. PhD Thesis, Universidad de Alicante

69. MINAG (2015) Mapa de balance de tierra 1:25 000. Instituto de suelos, Departamento de suelos y Fertilizantes

70. Montalvo JF, Perigó AE, Martínez M, García I, Esponda SC, César ME, Blanco M (2010) Compuestos de nitrógeno y fósforo en las aguas superficiales de tres zonas de la plataforma marina cubana. Ser Oceanol, 27-36 
71. Montgomery DR, Huang MY, Huang AY (2014) Regional soil erosion in response to land use and increased typhoon frequency and intensity Taiwan. Quat Res 81:15-20

72. Morgan RPC (2005) Soil erosion and conservation, 3rd edn. Blackwell Science Ltd, London

73. Morgan RP (2001) A simple approach to soil loss prediction. a revised Morgan-Morgan-Finney model. Netherlands. CATENA 44:305-322

74. Mörth C-M, Humborg C, Eriksson H, Danielsson Å, Medina Rodriguez M, A Rahm L (2007) Modeling riverine nutrient transport to the Baltic Sea: a large-scale approach. AMBIO J Hum Environ 36:124-133

75. Napoli M, Marta A, Zanchi C, Orlandini S (2017) Assessment of soil and nutrient losses by runoff under different soil management practices in an Italian hilly vineyard. Soil Tillage Res $168: 71-80$

76. NC DENR (2009) Falls lake watershed analysis risk management framework (WARMF) development

77. Nikolaidis N, Heng H, Semagin R, Clausen J (1998) Non-linear response of a mixed land use watershed to nitrogen loading. Agr Ecosyst Environ 67(2-3):251-265

78. Nuñes Jiménez A, Viña Bayes N, Graña González A (1989) Carsología 1: 1000 000. En I. d. Cartografía. Nuevo Atlas Nac Cuba. La Habana

79. Oblinger C, Cuffney T, Meador M, Garrett R (2002) Water-quality and physical characteristics of streams in the treyburn development area of falls lake watershed, North Carolina, 1994-98. Water-Resources Investigations Report, United States Geological Survey

80. Ouyang W, Hao F, Skidmore AK, Toxopeus AG (2010) Soil erosion and sediment yield and their relationships with vegetation cover in upper stream of the Yellow River. Sci Total Environ 409:396-403

81. Paneque J, Fuentes E, Mesa A, Echemendía A (1991) El mapa nacional de suelos escala 1:25 000. En: Villegas DR, Ponce de León D (eds) Memorias del XI congreso Latinoamericano y II Congreso Cubano de la Ciencia del Suelo, La Habana, Memorias

82. Planos G (2014) Sintesis informativa sobre impactos del cambio climatico y medidas de adaptacion en Cuba. Proyecto Basal (Bases Ambientales para Sostenibilidad Alimentaria Local), Habana

83. Poesen J, Ingelmo-Sanchez F (1992) Runoff and sediment yield from topsoils with different porosity as affected by rock fragment cover and position. CATENA 19(5):451-474

84. Ramos M, Martínez-Casasnovas J (2006) Nutrient losses by runoff in vineyards of the Mediterranean Alt Penedès region (NE Spain). Agr Ecosyst Environ 113:356-363

85. Ree WO (1949) Hydraulic characteristic of vegetation for vegetated waterways. Agric Eng 30(184-7):189

86. Sakinatu I, Muhammad AA (2017) Impact of soil erosion and degradation on water quality: a review. Geol Ecol Landsc. https ://doi.org/10.1080/24749508.2017.1301053

87. Schlesinger WH, Bernhardt ES (2013) Biogeochemistry: an analysis of global change. Academic press, Cambridge
88. Shields C, Band L, Law N, Groffman P, Kaushal S, Savvas K, Belt K (2008) Streamflow distribution of non-point source nitrogen export from urban-rural catchments in the Chesapeake Bay Watershed. Water Resour Res 44(9)

89. Soca Núñez M (2017) Efecto de la erosión sobre la fertilidad de diferentes tipos de suelos de las cuencas hidrográficas. Ministerio de Agricultura (MINAG), Cuba, Departamento de Suelos y Fertilizante. Obtenido de. https://repositorio.geotech.cu/xmlui /handle/1234/3245

90. Soto RP, Areces JA, Milián RP, Gómez SC, de León González ME (2017) La sustentabilidad en la pesquería de la langosta espinosa (Panulirus argus) en el golfo de Batabanó, Cuba. II. Indicadores multidimensionales. Rev Cuba Investig Pesq 34:0138-8452

91. Strahler A (1964) Quantitative geomorphology of drainage basins and channel networks. En V. Chow, Handbook of Applied Hydrology. New York-USA, Graw-Hill, Mc

92. Tremols Hernandez A, Rosario A, Morales M, Rodriguez J (2006) Mapa de Suelos de Cuba, escala 1:500000. En : Nelson Martin A, Alonso Martin C, Pedologia tomo I. La Habana

93. Vadas PA, Powell JM (2013) Monitoring nutrient loss in runoff from dairy cattle lots. Agr Ecosyst Environ. https://doi. org/10.1016/j.agee.2013.09.025

94. Valiela I, Collins G, Kremer J, Lajtha K, Geist M, Seely M, Sham C (1997) Nitrogen loading from coastal watersheds to receiving estuaries: new method and application. Ecol Appl 7(2):358-380

95. Van Beynen P, Towsend K (2005) A disturbance index for karst environments. Environ Manag 36:101-116

96. Vega Carreño MB, Febles González JM (2005) La investigación de suelos erosionados: métodos e índices. Min Geol 21(2):18

97. Vega M, Febles JM, Amaral NM, Tolón A, Lastra X (2013) Aplicación del modelo MMF en la evaluación de la erosión de los suelos en las alturas cársicas del distrito pecuario "Nazareno." Rev Cuba Cienc Agríc 47(1):67-73

98. Verstraeten G, Poesen J (2001) Modelling the long-term sediment trap efficiency of small ponds. Hydrol Process. https://doi. org/10.1002/hyp.269

99. Verstraeten G, Poesen J (2002) Regional scale variability in sediment and nutrient delivery from small agricultural watersheds. J Environ Qual 31:870-879

100. Withers $P$, Jarvie $H$, Stoate $C$ (2011) Quantifying the impact of septic tank systems on eutrophication risk in rural headwaters. Environ Int. https://doi.org/10.1016/j.envint.2011.01.002

101. Yu WD (2008) Water pollution and control in Zhangweinan River Basin. Water Resour Prot 24:83-86

102. Yue FJ, Waldron S, Li SL, Wang ZJ, Zeng J, Xu S, Oliver DM (2019) Land use interacts with changes in catchment hydrology to generate chronic nitrate pollution in karst waters and strong seasonality in excess nitrate export. Sci Total Environ 696:134062

Publisher's Note Springer Nature remains neutral with regard to jurisdictional claims in published maps and institutional affiliations. 